\title{
Microencapsulation of Lactobacillus acidophilus NCFM incorporated with mannitol and its storage stability in mulberry tea
}

\section{Microencapsulação de NCFM de Lactobacillus acidophilus com manitol e sua estabilidade de armazenamento em chá de amoreira}

\author{
Wong Lok Yee ${ }^{1} \mathbb{D}$, Chan Li Yee ${ }^{1} \mathbb{D}$, Nyam Kar Lin' ${ }^{1}$, Pui Liew Phing ${ }^{1 *} \mathbb{D}$
}

'UCSI University, Faculty of Applied Sciences, Department of Food Science with Nutrition, Kuala Lumpur, Malaysia

${ }^{*}$ Corresponding Author: puilp@ucsiuniversity.edu.my

Received in March 11, 2018 and approved in May 27, 2019

\begin{abstract}
Lactobacillus acidophilus NCFM (L-NCFM) was microencapsulated via co-extrusion technique with mannitol. Optimization of coating material, locust bean gum $(0 \%$ to $2 \%, \mathrm{w} / \mathrm{v})$ and prebiotic, mannitol $(0 \%$ to $5 \%, \mathrm{w} / \mathrm{v})$ was tested on bead size and microencapsulation efficiency. L-NCFM cells microencapsulated in three different forms were tested in simulated gastric juice $(\mathrm{pH} 2.0)$ and simulated intestinal juice $(\mathrm{pH}$ 7.5) and storage test at $4{ }^{\circ} \mathrm{C}$ and $25^{\circ} \mathrm{C}$ for 4 weeks. $0.5 \%(\mathrm{w} / \mathrm{v})$ locust bean gum and $3 \%(\mathrm{w} / \mathrm{v})$ of mannitol are the optimal concentrations to produce bead size of $570 \mu \mathrm{m}$, microencapsulation efficiency of $96.81 \%$ and cell count $8.92 \mathrm{log} \mathrm{CFU} / \mathrm{mL}$. Microencapsulation of L-NCFM with mannitol protect cells better in acidic environment. The viability of encapsulated L-NCFM with mannitol at $4{ }^{\circ} \mathrm{C}$ throughout the storage period for 30 days ranged from $8.62 \log \mathrm{cfu} / \mathrm{mL}$ to $6.80 \log \mathrm{cfu} / \mathrm{mL}$, which met the minimum required for probiotic $\left(10^{6} \mathrm{CFU} / \mathrm{mL}\right)$.
\end{abstract}

Index terms: Probiotic; co-extrusion; mannitol; Lactobacillus.

\begin{abstract}
RESUMO
Lactobacillus acidophilus NCFM (L-NCFM) foi microencapsulado pela técnica de coextrusão com manitol. A otimização do material de revestimento, goma de alfarroba ( $0 \%$ a $2 \%, \mathrm{p} / \mathrm{v})$ e prebiótico, manitol $(0 \%$ a $5 \%$, p / v) foi testada no tamanho do grânulo e eficiência de microencapsulação. Células L-NCFM microencapsuladas em três formas diferentes foram testadas em suco gástrico simulado ( $\mathrm{pH} 2,0)$ e suco intestinal simulado $(\mathrm{pH} 7,5)$ e teste de armazenamento a $4{ }^{\circ} \mathrm{C}$ e $25^{\circ} \mathrm{C}$ por 4 semanas. $0,5 \%(\mathrm{p} / \mathrm{v})$ de goma de alfarroba e $3 \%(\mathrm{p} / \mathrm{v})$ de manitol são as concentrações óptimas para produzir um tamanho de pérola de 570 m, eficiência de microencapsulação de $96,81 \%$ e contagem de células 8,92 log CFU / mL. A microencapsulação de L-NCFM com manitol protege melhor as células em ambiente ácido. A viabilidade de L-NCFM encapsulado com manitol a $4{ }^{\circ} \mathrm{C}$ durante o período de armazenamento por 30 dias variou de $8,62 \mathrm{log}$ ufc $/ \mathrm{mL}$ a 6,80 log ufc / $\mathrm{mL}$, atendendo ao mínimo necessário para probiótico $\left(10^{6} \mathrm{UFC} / \mathrm{mL}\right)$.
\end{abstract}

Termos para indexação: Probiótico; co-extrusão; manitol; Lactobacillus.

\section{INTRODUCTION}

Over recent decades, development of functional foods such as probiotic product has been becoming more rapid. Probiotic is defined by the World Health Organization as "live microorganisms such as bacteria or yeasts, which when administered in adequate amounts confer health benefits to the host" (Food and Agriculture Organization; World Health Organization, 2002). Probiotics have traditionally been categorized as food supplements which can confer to human health. Probiotic product can be divided into sub-categories of probiotic food, probiotic supplement, probiotic drug, designer probiotic which is genetically modified microbe and direct-fed microbial which is used for animal (Sanders, 2009).
Consumption of probiotics can help in maintaining health-promoting gut microflora, stimulating the host's immune system and inhibiting growth of pathogen (Figueroa-Gonzalez et al., 2011). To confer these benefits to human, probiotics must be viable which they have to hinge on their survival through the critical condition of processing and throughout human gastrointestinal tract. Thus, probiotic strain must be able to tolerate harsh conditions such as low pH environment (Shewale et al., 2014). The most commonly used probiotics genus are Lactobacillus and Bifidobacterium.

Lactobacillus acidophilus NCFM is proven as generally recognized as safe (GRAS), which is safe to be consumed and permitted in food according to Food 
(Amendment) (No. 2) Regulations 2017 (Aseanlip, 2017). Lactobacillus acidophilus NCFM was reported to improve the intestinal environment condition of human body and balancing enteric microbes (Sohail, Turner; Coombes, 2013). Probiotics must be in viable state and survive through harsh condition in human gastrointestinal tract. Thus, microencapsulation can be used to protect the probiotic and enhance its survivability in harsh condition and under long time storage. It is a technique that helps in stabilizing of particles, protection as well as isolation of active core material from surroundings (Butstraen; Salaün, 2014). Microencapsulation of probiotics using alginate, resistant starch, gelatin, chitosan and vegetable gum were reported to provide protection to Bifidobacteria and Lactobacilli (Ortakci; Sert, 2012; Soodbakhsh et al., 2012; Abbaszadeh et al., 2004).

Prebiotic is defined as non-digestible compounds that improve the growth and activity of probiotic and is known to have a positive effect on human health (Zanjani et al., 2017). The introduction of prebiotics such as fructooligosaccharides (FOS), inulin, pectin, mannitol and maltodextrin to probiotics helps in improving the growth of probiotics (Succi et al., 2017; Yeo; Liong, 2010). Combining probiotic and prebiotic agents is termed "synbiotics" and this can improve the survival of bacteria in the upper gastrointestinal tract and enhance their effect in the large bowel (Nazzaro et al., 2009). An example of prebiotics is mannitol. Mannitol is a sugar alcohol with indigestibility properties has been grouped as prebiotic (Succi et al., 2017).

Probiotics such as Bifidobacterium species and lactic acid bacteria, especially Lactobacillus strains, are commonly used in food production, for examples, Bifidobacterium species and lactic acid bacteria, especially in fruit-based, fruit tea-based and vegetable-based products, such as carrot, beet, celery, green cucumber and clover (Angelov et al., 2006; Granato et al., 2010; Shurkhna et al., 2006).

Mulberry tea is a type of fruit tea. Mulberry is known as Morus alba L. which is from the family of Moraceae, genera Morus is rich in natural isoprenoid substituted phenolic compounds including flavonoids (Deepa et al., 2012; Kumar; Chauhan, 2008). Mulberry leaf tea contains nutritious compound that can confer to human health. For example, it acts as anti-atherosclerotic, anti-diabetic, anti-obesity, antimicrobial, antioxidant, cardioprotective, cognitive enhancement activities, induces apoptosis in human breast cancer and colon cancer cells and skinwhitening (Chan; Lye; Wong, 2016; Deepa et al., 2012; Du et al., 2008; Haurama et al., 2007; Peng et al., 2011).
To date, most of the probiotics are commonly present in dairy product (Gawkowski; Chikindas, 2013). Thus, patients with lactose intolerance are not able to obtain probiotics through diary probiotic products. Cholesterol content in dairy product and the development of vegetarianism also increase the urge of developing dairy-free probiotic product. The probiotic in the probiotic product must be able to survive through harsh condition such as human gastrointestinal tract and long term storage. Thus, the purpose of this study is to employ co-extrusion technique to protect Lactobacillus acidophilus NCFM during gastrointestinal transit and long term storage in mulberry tea.

\section{MATERIAL AND METHODS}

\section{Optimization of locust bean gum}

In order to optimize the concentration of locust bean gum, the concentration of alginate was fixed at $1.5 \%(\mathrm{w} / \mathrm{v})$. Microencapsulation process was carried out using different concentration of locust bean gum solution which were $0.5 \%(\mathrm{w} / \mathrm{v}), 1.0 \%$ $(\mathrm{w} / \mathrm{v}), 1.5 \%(\mathrm{w} / \mathrm{v})$ and $2.0 \%(\mathrm{w} / \mathrm{v})$. Bead size and microencapsulation efficiency were used to determine optimum concentration of locust bean gum.

\section{Optimization of mannitol}

In order to optimize the concentration of mannitol, the concentration of locust bean gum was fixed at $0.5 \%$ $(\mathrm{w} / \mathrm{v})$, respectively. Microencapsulation process was repeated using different concentration of mannitol solution at $1.0 \%(\mathrm{w} / \mathrm{v}), 2.0 \%(\mathrm{w} / \mathrm{v}), 3.0 \%(\mathrm{w} / \mathrm{v}), 4.0 \%(\mathrm{w} / \mathrm{v})$ and $5.0 \%(\mathrm{w} / \mathrm{v})$. The optimum concentration of mannitol extract was determined based on average cell count by expressing viable cell counts in colony forming unit per millilitre $(\mathrm{CFU} / \mathrm{mL})$ and were then converted into $\log$ $\mathrm{CFU} / \mathrm{mL}$ (Equation 1). Microencapsulation efficiency was calculated using Equation 2.

Colony forming unit $(\mathrm{CFU} / \mathrm{mL})=\frac{\text { Average number of colonies }}{\text { Dilution factor } \times \text { volume plated }}$

Microencapsulation efficiency $(\%)=\left(\log _{10} \mathrm{~N} / \log _{10} \mathrm{~N}_{0}\right) \times 100$

where $\mathrm{N}$ represents the number of microencapsulated probiotics released from beads, and $\mathrm{N}_{0}$ represents the number of probiotics in the initial microbial suspension. 


\section{Microencapsulation of L-NCFM using co-extrusion technique}

Büchi Encapsulator B-390 (Büchi, India) was used to conduct microencapsulation of co-extrusion method according to Chew et al. (2015) with modification. Before conducting microencapsulation, all media and glassware were sterilized at $121{ }^{\circ} \mathrm{C}$ for 15 minutes. The core fluid (comprised of L-NCFM suspended in PBS with or without mannitol) and shell fluid (sodium alginate solution) were added into two separate pressured bottles connected to Büchi Encapsulator B-390 machine. Diameter for concentric nozzle (inner nozzle) and shell nozzle used were $200 \mu \mathrm{m}$ and $300 \mu \mathrm{m}$, respectively. During microencapsulation, core fluid and shell fluid were pumped simultaneously through concentric nozzle and shell nozzle by 600 mbar of pressure, $300 \mathrm{~Hz}$ of vibration frequency, amplitude of 3 and $1.5 \mathrm{kV}$ of voltage.

\section{Morphology and size of bead}

Optical microscope (Olympus, Japan) with $\mathrm{x} 100$ magnification was used to determine and measure the morphology and mean diameter of 50 randomly selected beads. To measure size of beads, the microscope was fitted with calibrated micrometer scale (Annan et al., 2008).

\section{Preparation of simulated gastrointestinal juice}

Simulated gastric juice (SGJ) was prepared according to Chia et al. (2015) with modification. To prepare SGJ, $1 \mathrm{~g}$ sodium chloride (R\&M Chemicals, UK) and 3.5 mL 0.1 M hydrochloric acid (Merck KGaA, Germany) were mixed with $500 \mathrm{~mL}$ distilled water. After that, $\mathrm{pH}$ was adjusted to 2.0 by using hydrochloric acid with aid of $\mathrm{pH}$ meter (Eutech Instrument, USA). The solution was sterilized at $121{ }^{\circ} \mathrm{C}$ for 15 minutes. The sterilized solution was left to cool down at room temperature. $1.6 \mathrm{~g}$ pepsin (Chemsoln, India) was added to the cooled down solution. The cooling step was carried out to prevent denaturation of protein which was pepsin enzyme under high temperature. Simulated intestinal juice (SIJ) was prepared according to Chia et al. (2015) with modification. To prepare SGJ, $3.4 \mathrm{~g}$ potassium dihydrogen phosphate (Bendosen, Germany), $125 \mathrm{~mL}$ distilled water and $95 \mathrm{~mL} 0.1 \mathrm{M}$ sodium hydroxide (Merck KGaA, Germany) were mixed and topped up with distilled water to $500 \mathrm{~mL}$. The $\mathrm{pH}$ of SIJ was adjusted to 7.5 by using hydrochloric acid with aid of $\mathrm{pH}$ meter. The solution was sterilized at $121{ }^{\circ} \mathrm{C}$ for 15 minutes. After the solution was cooled to room temperature, $3 \mathrm{~g}$ bile salt (Chemsoln, India) was added.

\section{Sequential digestion}

Sequential digestion was carried out according to method by Sathyabama et al. (2014) with modification. Simulated gastric juice (SGJ) was prepared by dissolving $1 \mathrm{~g}$ sodium chloride (R\&M Chemicals, UK) and $3.5 \mathrm{~mL}$ $0.1 \mathrm{M}$ hydrochloric acid (Merck KGaA, Germany) into $500 \mathrm{~mL}$ of distilled water. Simulated intestinal juice (SIJ) was prepared by adding $3.4 \mathrm{~g}$ potassium dihydrogen phosphate (Bendosen, Germany), $125 \mathrm{~mL}$ distilled water and mixed with $95 \mathrm{~mL} 0.1 \mathrm{M}$ sodium hydroxide (Merck KGaA, Germany) and followed by topping up with distilled water to $500 \mathrm{~mL}$. In order to evaluate the survivability of L-NCFM under simulated gastrointestinal condition, $1 \mathrm{~mL}$ free cells or $1 \mathrm{~g}$ beads (with or without mannitol) were added to $15 \mathrm{~mL}$ falcon tube (BD Falcon ${ }^{\mathrm{TM}}$, USA) containing $9 \mathrm{~mL}$ sterile $\mathrm{SGJ}$ at $\mathrm{pH} 2.0$. It was then incubated at $37^{\circ} \mathrm{C}$ for 0 hour, 1 hour, and 2 hours with constant agitation in water bath (Memmert, Germany). After 2 hours of gastric digestion, both free cells and beads were adjusted to $\mathrm{pH} 6.8$ with $1.0 \mathrm{M}$ sodium hydroxide immediately to inactivate pepsin. Centrifugation was carried out at $6000 \times \mathrm{g}, 4{ }^{\circ} \mathrm{C}$ for 10 minutes to remove SGJ. SIJ with the volume of $9 \mathrm{~mL}$ was then was added into free cells or beads. The mixture was mixed gently at $150 \mathrm{rpm}$ and followed by sequential incubation at $37^{\circ} \mathrm{C}$ for 3 hours, 4 hours, 5 hours and 6 hours with constant agitation at $100 \mathrm{rpm}$ in water bath. After incubation, the mixture was centrifuged at $6000 \times g, 4^{\circ} \mathrm{C}$ for 10 minutes to retrieve the beads. Before cell enumeration, free cells pellet that was obtained after centrifugation was resuspended in PBS. For beads, $9 \mathrm{~mL} \mathrm{10 \%} \mathrm{(w/v)} \mathrm{tri-sodium} \mathrm{citrate} \mathrm{(Merck}$ $\mathrm{KGaA}$, Germany) was added and followed by vortexing to release probiotics from retrieved beads. To enumerate the cells, spread plate method was used by spreading aliquot of $0.1 \mathrm{~mL}$ of mixture on MRS agar plate. It was incubated anaerobically at $37^{\circ} \mathrm{C}$ for 24 hours. The viable cell counts for beads and free cells were expressed as logarithm colony forming unit per gram $(\log \mathrm{CFU} / \mathrm{g})$ and logarithm colony forming unit per milliliter $(\log \mathrm{CFU} / \mathrm{mL})$, respectively. According to Lotfipour, Mirzaeei and Maghsoodi (2012), survivability (\%) of probiotic after exposure to SGJ and SIJ was calculated using Equation 3.

Survivability $(\%)=\log _{10} \mathrm{~N}_{\mathrm{t}} / \log _{10} \mathrm{~N}_{0} \times 100$

$\mathrm{N}_{\mathrm{t}}$ is the number of viable cells in free cell $(\mathrm{CFU} / \mathrm{mL})$ or beads (CFU/g) after exposure to SGJ or SIJ, and $\mathrm{N}_{0}$ is the number of viable cells in free cell $(\mathrm{CFU} / \mathrm{mL})$ or beads $(\mathrm{CFU} / \mathrm{g})$ at 0 hour. 
Evaluation of probiotics viability during storage in mulberry leaf tea

Preparation of mulberry tea was prepared according to Taufik, Widiantara and Garnida (2016) with modification. Mulberry leaf tea was prepared by picking it from the tree. After that, it was cut into the size of $2 \mathrm{~mm}$. It was then oven-dried at $50{ }^{\circ} \mathrm{C}$ for 4 hours. Hot boiled water was added to the mulberry leaf to make mulberry leaf tea. Evaluation of viability during storage in mulberry tea was tested for one month. To prepare mulberry tea with bacteria, $1 \mathrm{~g}$ bead was added in $9 \mathrm{~mL}$ mulberry tea for three forms of L-NCFM which were free cells, encapsulated L-NCFM with and without mannitol. Three forms of L-NCFM were put into mulberry tea and were kept at $25^{\circ} \mathrm{C}$ and refrigerator $4{ }^{\circ} \mathrm{C}$. Enumeration by MRS agar (Chemsoln, India) was carried out and the viable cells were tested weekly.

\section{Statistical analysis}

The experiments were performed in triplicate $(\mathrm{n}=3)$. The results were presented in mean \pm standard deviation. Analysis of data was carried out by MINITAB 17 statistical analysis. Results were calculated through mean value and standard deviation whereas significant difference was analyzed through One-way analysis of variance (ANOVA) and Tukey's post hoc test. The significant difference was set at $\mathrm{p}<0.05$.

\section{RESULTS AND DISCUSSION}

\section{Optimization of locust bean gum concentration}

Optimization process was carried out to determine the optimal concentration of locust bean gum (Sigma Aldrich, UK) as coating material and mannitol (Chemsoln, India) as prebiotic in microencapsulation of Lactobacillus acidophilus NCFM (L-NCFM). Table 1 presents the results of coating effects for different locust bean gum concentration on size and microencapsulation efficiency of alginate microencapsulation L-NCFM beads. From Table 1, it was observed that increased locust bean gum concentration had no significant effect $(\mathrm{p}>0.05)$ on bead size. This aligns with Cheow, Kiew and Hadinoto (2014) where it is reported that the concentration of locust bean gum does not influence the size of beads. The range of beads size produced are within $550 \mu \mathrm{m}$ to $673.33 \mu \mathrm{m}$.

From Table 1, it was found that when the concentration of locust bean gum increased from $0.5 \%$ $(\mathrm{w} / \mathrm{v})$ to $1.5 \%(\mathrm{w} / \mathrm{v})$, microencapsulation efficiency of bead decreased from $94.70 \%$ to $89.21 \%$. The microencapsulation efficiency of bead increased with the increasing concentration of locust bean gum from $1.5 \%(\mathrm{w} / \mathrm{v})$ to $2.0 \%(\mathrm{w} / \mathrm{v})$, which was from $89.21 \%$ to $93.34 \%$. The microencapsulation efficiency of beads produced by $0.5 \%(\mathrm{w} / \mathrm{v})$ and $2.0 \%(\mathrm{w} / \mathrm{v})$ locust bean gum had no significant difference ( $\mathrm{p}>0.05)$, thus $0.5 \%(\mathrm{w} / \mathrm{v})$ locust bean gum was selected as its microencapsulation efficiency because it produced beads with desired diameter which are larger than $100 \mu \mathrm{m}$ but smaller than $1 \mathrm{~mm}$. It had a higher microencapsulation efficiency compared other concentrations of locust bean gum. Smaller beads are desired as it can enhance the sensory property of the end food product (Hansen et al., 2002). Higher microencapsulation efficiency shows that a higher number of viable cells are released from the beads during enumeration of cells.

\section{Optimization of mannitol concentration}

Table 2 shows the effect of different concentration of mannitol on average $\log \mathrm{CFU} / \mathrm{mL}$, bead size and microencapsulation efficiency of locust bean gum coated microencapsulated L-NCFM. The average cell

Table 1: Effect of different concentration of locust bean gum on bead size and microencapsulation efficiency of locust bean gum coated microencapsulated L-NCFM.

\begin{tabular}{ccc}
\hline $\begin{array}{c}\text { Locust bean gum } \\
(\%, \mathrm{w} / \mathrm{v})\end{array}$ & $\begin{array}{c}\text { Diameter } \\
(\mu \mathrm{m})\end{array}$ & Microencapsulation efficiency $(\%)$ \\
\hline 0.0 & $550.00 \pm 55.68^{\mathrm{b}}$ & $93.70 \pm 0.79^{\mathrm{a}}$ \\
0.5 & $576.67 \pm 47.26^{\mathrm{ab}}$ & $94.70 \pm 0.62^{\mathrm{a}}$ \\
1.0 & $613.33 \pm 15.28^{\mathrm{ab}}$ & $90.27 \pm 0.21^{\mathrm{b}}$ \\
1.5 & $673.33 \pm 25.17^{\mathrm{a}}$ & $89.21 \pm 0.68^{\mathrm{b}}$ \\
2.0 & $623.33 \pm 28.87^{\mathrm{ab}}$ & $93.34 \pm 0.81^{\mathrm{a}}$ \\
\hline
\end{tabular}

a-b Means \pm standard deviations followed by different superscript letters within the same column are significantly different at $p$ $<0.05$ according to Tukey's test. 
count for both $1.0 \%(\mathrm{w} / \mathrm{v})$ and $2.0 \%(\mathrm{w} / \mathrm{v})$ mannitol had no significant difference $(\mathrm{p}>0.05)$ when compared to $0 \%(\mathrm{w} / \mathrm{v})$ mannitol. This suggests that the addition of mannitol at $1.0 \%(\mathrm{w} / \mathrm{v})$ and $2.0 \%(\mathrm{w} / \mathrm{v})$ were not sufficient to improve the cell viability. The concentration of mannitol at $3.0 \%(\mathrm{w} / \mathrm{v})$ demonstrated the highest viable cell count compared to cells with different concentration of mannitol or without mannitol. This shows that 3\% $(\mathrm{w} / \mathrm{v})$ mannitol is the optimum concentration of mannitol that it is able to enhance the growth of L-NCFM with mannitol. Mannitol prebiotic serves as food for probiotic where several studies revealed that it improved the growth of different types of Lactobacillus (Succi et al., 2017; Yeo; Liong, 2010).

The increased of mannitol concentration is not directly proportional to the increment of bead size (Table 2), indicating that the size of beads does not depend on increasing concentration of mannitol. The size of bead is not influenced by the concentration of prebiotic, resulting in variation of beads size with the increasing concentration of (Haghshenas et al., 2015). Variation was found in the microencapsulation efficiency of beads, indicating that microencapsulation efficiency of beads does not depend on the type and concentration of prebiotic used (Gandomi et al., 2016).

The optimization process demonstrated that $3 \%$ $(\mathrm{w} / \mathrm{v})$ of mannitol has the desired characteristics to conduct further experiment as it had a higher in average viable cell count, smaller bead size and higher microencapsulation efficiency compared to other concentration of mannitol used. Smaller beads can enhance sensory property of the end food product whereas higher microencapsulation efficiency shows that there a higher number of viable cells that can be released from the beads during enumeration of cells.

\section{Morphology and size of bead}

Microencapsulation of probiotic L-NCFM was conducted using co-extrusion technique. Optical microscope (Olympus, Japan) with stage micrometer (Ladd Research, USA) was used to observe the size and shape of beads. Figure 1 shows the size and shape of bead produced by microencapsulation with shell material sodium alginate (R\&M Chemicals, UK), coating material locust bean gum (Sigma Aldrich, UK) and hardening agent of calcium chloride (R\&M Chemicals, UK).

Beads produced are white in color and are surrounded by a thin membrane layer. The range of bead size produced by co-extrusion microencapsulation with different concentrations of locust bean gum and prebiotic are between $550 \mu \mathrm{m}$ and $700 \mu \mathrm{m}$. The size are between $550 \mu \mathrm{m}$ and $700 \mu \mathrm{m}$ is in the range of microcapsule size, which is between $3 \mathrm{~mm}$ and 800 $\mathrm{mm}$ (Jyothi et al., 2010). According to Hansen et al. (2002), coarseness of texture in live microbial feed supplements is observed when the size of beads are large $(>1 \mathrm{~mm})$ while when the bead size is too small $(<100 \mu \mathrm{m})$, the bacteria are not protected in SGJ when compared to free cells. The beads size produced in this study are within the suitable range which are smaller than $1 \mathrm{~mm}$ but larger than $100 \mu \mathrm{m}$.

Observation of the shape of beads through optical microscope showed that most of the beads are in spherical shape but there are some beads observed are in irregular oval or tailed shaped. Beads with irregular surface are more likely to suffer from collapsing or bursting as it will be not able to shield and protect the core cells (Krasaekoopt et al., 2013). Optimum concentration of coating material locust bean gum, shell material alginate and hardening agent calcium chloride were used in this study to produce beads with optimum size and shape. Table 3 shows average $\log _{10} \mathrm{CFU} / \mathrm{mL}$, bead size in diameter and microencapsulation efficiency of L-NCFM with or without locust bean gum and mannitol.

Table 2: Effect of different concentration of mannitol on average log CFU/mL, bead size and microencapsulation efficiency of locust bean gum coated microencapsulated L-NCFM.

\begin{tabular}{cccc}
\hline $\begin{array}{c}\text { Mannitol } \\
(\%, w / v)\end{array}$ & Average $\log _{10}$ CFU/mL & $\begin{array}{c}\text { Diameter } \\
(\mu \mathrm{m})\end{array}$ & $\begin{array}{c}\text { Microencapsulation efficiency } \\
(\%)\end{array}$ \\
\hline 0.0 & $7.54 \pm 0.17^{\mathrm{d}}$ & $543.33 \pm 30.55^{\mathrm{b}}$ & $95.88 \pm 1.18^{\mathrm{a}}$ \\
1.0 & $7.41 \pm 0.08^{\mathrm{d}}$ & $576.67 \pm 25.17^{\mathrm{b}}$ & $85.86 \pm 1.34^{\mathrm{c}}$ \\
2.0 & $7.47 \pm 0.02^{\mathrm{d}}$ & $613.33 \pm 35.12^{\mathrm{ab}}$ & $91.92 \pm 0.78^{\mathrm{b}}$ \\
3.0 & $8.92 \pm 0.08^{\mathrm{a}}$ & $570.00 \pm 50.00^{\mathrm{b}}$ & $96.81 \pm 0.86^{\mathrm{a}}$ \\
4.0 & $7.92 \pm 0.11^{\mathrm{c}}$ & $670.00 \pm 20.00^{\mathrm{a}}$ & $94.37 \pm 0.62^{\mathrm{ab}}$ \\
5.0 & $8.39 \pm 0.16^{\mathrm{b}}$ & $610.00 \pm 26.46^{\mathrm{ab}}$ & $93.57 \pm 0.89^{\mathrm{ab}}$ \\
\hline
\end{tabular}

${ }^{a-d}$ Means \pm standard deviations followed by different superscript letters within the same column are significantly different at $p$ $<0.05$ according to Tukey's test. 


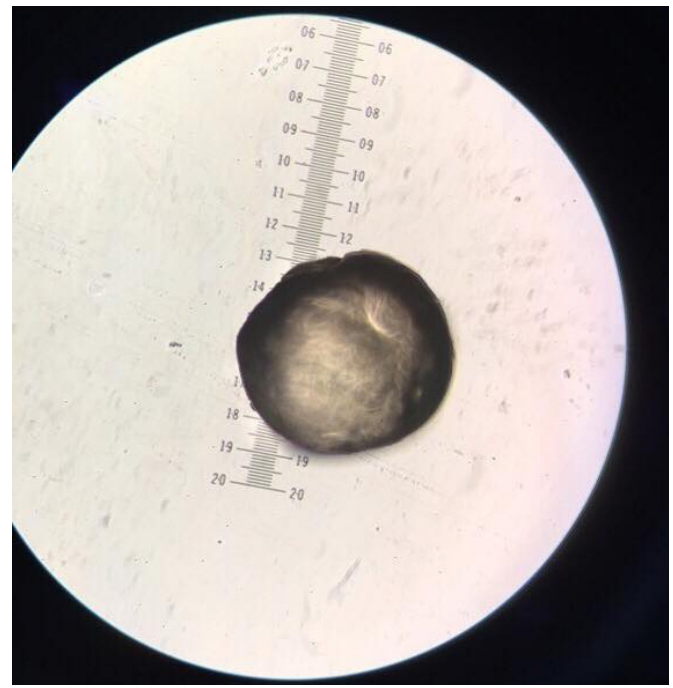

Figure 1: Size and shape of beads measured with a scale micrometer.
Encapsulated L-NCFM with mannitol was chosen to conduct further analysis as it has high average cell count, small bead size and high microencapsulation efficiency. This result is in agreement with Succi et al. (2017) which proved that mannitol serves as food for probiotic to improve the growth of different types of Lactobacillus. The strength of shell material can be enhanced by locust bean gum (Shi et al., 2013).

\section{Sequential Digestion for free cell and encapsulated L-NCFM with and without mannitol}

Table 4 shows the average $\log _{10} \mathrm{CFU} / \mathrm{mL}$ and survivability of free cell, encapsulated L-NCFM with and without mannitol under sequential digestion. Based on the table, survivability of free cell, encapsulated L-NCFM with and without mannitol demonstrated a decreasing trend. The survivability of all three forms of L-NCFM decreased throughout 2 hours of SGJ incubation.

Table 3: Average $\log _{10} \mathrm{CFU} / \mathrm{mL}$, bead size in diameter and microencapsulation efficiency of L-NCFM.

\begin{tabular}{cccccc}
\hline Probiotic & Prebiotic & Coating material & $\begin{array}{c}\text { Average } \log _{10} \\
\text { CFU } / \mathrm{mL}^{10}\end{array}$ & $\begin{array}{c}\text { Diameter } \\
(\mu \mathrm{m})\end{array}$ & $\begin{array}{c}\text { Microencapsulation efficiency } \\
(\%)\end{array}$ \\
\hline L-NCFM & - & - & $7.54 \pm 0.17^{\mathrm{b}}$ & $550.00 \pm 55.68^{\mathrm{a}}$ & $93.70 \pm 0.79^{\mathrm{b}}$ \\
L-NCFM & - & Locust bean gum & $7.54 \pm 0.17^{\mathrm{b}}$ & $576.67 \pm 47.26^{\mathrm{a}}$ & $95.88 \pm 1.28^{\mathrm{ab}}$ \\
L-NCFM & Mannitol & Locust bean gum & $8.92 \pm 0.08^{\mathrm{a}}$ & $570.00 \pm 50.00^{\mathrm{a}}$ & $96.81 \pm 0.86^{\mathrm{a}}$ \\
\hline
\end{tabular}

a-b Means \pm standard deviations followed by different superscript letters within the same column are significantly different at $\mathrm{p}$ $<0.05$ according to Tukey's test. $\mathrm{S}_{1}$ : without mannitol without locust bean gum; $\mathrm{S}_{2}$ : without mannitol with locust bean gum; $\mathrm{S}_{3}$ : with mannitol with locust bean gum.

Table 4: Average $\log _{10} \mathrm{CFU} / \mathrm{mL}$ and survivability of free cell, encapsulated L-NCFM with and without mannitol under sequential digestion.

\begin{tabular}{|c|c|c|c|c|c|c|c|}
\hline \multirow[b]{2}{*}{$\begin{array}{l}\text { Sequential } \\
\text { incubation }\end{array}$} & \multirow[b]{2}{*}{$\begin{array}{l}\text { Time } \\
\text { (h) }\end{array}$} & \multicolumn{5}{|c|}{ Average $\log _{10}$ CFU/mL Survivability (\%) } & \multirow[b]{2}{*}{$\begin{array}{l}\text { Encapsulated } \\
\text { L-NCFM with } \\
\text { mannitol }\end{array}$} \\
\hline & & Free cell & $\begin{array}{c}\text { Encapsulated } \\
\text { L-NCFM }\end{array}$ & $\begin{array}{c}\text { Encapsulated } \\
\text { L-NCFM with } \\
\text { mannitol }\end{array}$ & Free cell & $\begin{array}{c}\text { Encapsulated } \\
\text { L-NCFM }\end{array}$ & \\
\hline \multirow{3}{*}{ SGJ (pH 2.0) } & 0 & $8.64 \pm 0.07^{\text {Аа }}$ & $0.40 \pm 0.04$ & $8.57 \pm 0.05^{\text {Aab }}$ & $100.00 \pm 0.00^{\mathrm{Aa}}$ & $100.00 \pm 0.00^{\mathrm{Aa}}$ & $100.00 \pm 0.00^{\mathrm{Aa}}$ \\
\hline & 1 & $6.67 \pm 0.03^{\mathrm{BC}}$ & $7.33 \pm 0.02^{\mathrm{Bb}}$ & $7.71 \pm 0.02^{\mathrm{Ba}}$ & $77.17 \pm 0.75^{\mathrm{Bc}}$ & $86.66 \pm 0.19^{\mathrm{Bb}}$ & $89.89 \pm 0.68^{\mathrm{Ba}}$ \\
\hline & 2 & $5.61 \pm 0.04 c c$ & $6.47 \pm 0.05^{\mathrm{cb}}$ & $6.72 \pm 0.03^{\mathrm{ca}}$ & $64.91 \pm 0.76^{c c}$ & $76.52 \pm 0.48^{\mathrm{cb}}$ & $78.38 \pm 0.44^{\mathrm{ca}}$ \\
\hline \multirow{4}{*}{ SIJ (pH 7.5) } & 3 & $3.49 \pm 0.03^{D C}$ & $5.78 \pm 0.10^{\mathrm{Db}}$ & $6.35 \pm 0.01 \mathrm{Da}$ & $40.38 \pm 0.47^{D C}$ & $68.30 \pm 0.95^{\mathrm{Db}}$ & $74.08 \pm 0.30^{\mathrm{Da}}$ \\
\hline & 4 & $0.00 \pm 0.00^{\mathrm{EC}}$ & $5.68 \pm 0.04^{\mathrm{Db}}$ & $6.21 \pm 0.04^{\mathrm{Da}}$ & $0.00 \pm 0.00^{\mathrm{EC}}$ & $67.21 \pm 0.19^{D b}$ & $72.35 \pm 0.85^{\mathrm{Da}}$ \\
\hline & 5 & $0.00 \pm 0.00^{\mathrm{EC}}$ & $3.62 \pm 0.03^{\mathrm{Eb}}$ & $4.72 \pm 0.03^{\text {Еа }}$ & $0.00 \pm 0.00^{\mathrm{Ec}}$ & $42.84 \pm 0.24^{\mathrm{Eb}}$ & $55.03 \pm 0.61$ Еа \\
\hline & 6 & $0.00 \pm 0.00^{\text {Еa }}$ & $0.00 \pm 0.00^{\mathrm{Fa}}$ & $0.00 \pm 0.00^{\mathrm{Fa}}$ & $0.00 \pm 0.00^{\text {Еа }}$ & $0.00 \pm 0.00^{\mathrm{Fa}}$ & $0.00 \pm 0.00^{\mathrm{Fa}}$ \\
\hline
\end{tabular}

A-F Means \pm standard deviations followed by different superscript letters within the same column are significantly different at $p$ $<0.05$ according to Tukey's test. ${ }^{a-c}$ Means \pm standard deviations followed by different superscript letters within the same row are significantly different at $p<0.05$ according to Tukey's test. 
Acidic $\mathrm{pH}$ condition and the presence of various enzymes can threaten the viability of probiotic (Cook et al., 2012). Incubation of free cell under gastric stress for 2 hours demonstrated a total free cell reduction of approximately $35.09 \%$. Non-encapsulated Lactobacillus acidophilus was sensitive to the acidic environment (Kim et al., 2008; Nazzaro et al., 2009).

Encapsulated L-NCFM without mannitol had smaller reduction in cells compared to free cell. The survivability of free cell was decreased more than the encapsulated L-NCFM after 2 hours of incubation in $\mathrm{pH} 2$. These results indicate that microencapsulated L-NCFM can survive better in extreme condition such as acidic $\mathrm{pH}$ in human stomach. Numerous studies have attempted to explain that there was a higher survival rate when lactobacillus encapsulated in alginate beads were incubated in SGJ compared to free cells as alginate beads can protect cells (Mortazavian et al., 2008; Sohail et al., 2013).

Encapsulated L-NCFM with mannitol showed the highest survivability in SGJ when compared to free cell and encapsulated L-NCFM without mannitol. After 2 hours of SGJ incubation, the survivability of encapsulated L-NCFM with mannitol was $78.38 \%$ which was higher than the survivability of free cells and encapsulated L-NCFM without mannitol which were $64.91 \%$ and $76.52 \%$. This result shows that the addition of mannitol helped to maintain survivability of probiotic in extreme condition such as low $\mathrm{pH}$ environment in human stomach. Several studies proved that prebiotic mannitol improved the growth of different types of Lactobacillus (Succi et al., 2017; Yeo; Liong, 2010). The viable bacteria count of encapsulated L-NCFM with or without mannitol achieved the minimum required concentration of probiotic of $10^{6}$ CFU/mL (Kechagia et al., 2013).

Both free cell, encapsulated L-NCFM with and without mannitol had a decreasing in survivability after 4 hours of SIJ incubation. Reduction in the survivability of probiotic was caused by stress from the bile salt in SIJ which could reduce the survivability of cells (Brinques; Ayub, 2011). After 3 hours of SIJ incubation, the reduction of survivability of free cell was $40.38 \%$ whereas survivability losses of encapsulated L-NCFM with and without mannitol were $25.46 \%$ and $19.05 \%$, respectively. Alginate-locust bean gum beads allowed the encapsulated cells to have a lower exposure to the extreme environment, which is manifested in the higher survivability of the alginatelocust bean gum beads in gastrointestinal digestion (Cheow, Kiew; Hadinoto, 2014).
Mannitol enhanced the survivability of encapsulated L-NCFM. At the first 3 hours of SIJ incubation, encapsulated L-NCFM with mannitol showed a higher survivability of cells compared to the others which is in agreement with several researches stated that prebiotic improved cell survivability and cell growth (Chen et al., 2015; Ooi; Liong, 2010; Succi et al., 2017). However, the survivability of L-NCFM after 4 hours of incubation in SIJ for all three forms of L-NCFM were $0 \%$. Both encapsulated L-NCFM and with mannitol did not survive after 5 hours of SIJ incubation which the reason is due to bursting of beads and released of cells into SIJ. This result is in agreement with Brinques and Ayub (2011) who stated that release of Lactobacillus plantarum could happen due to collapse or bursting of beads.

The effect of mannitol on encapsulated L-NCFM was tested. There was cell count of $6.21 \log _{10} \mathrm{CFU} / \mathrm{mL}$, $4.72 \log _{10} \mathrm{CFU} / \mathrm{mL}$ and $0 \log _{10} \mathrm{CFU} / \mathrm{mL}$ for encapsulated L-NCFM with mannitol after SIJ incubation of 2 hours, 3 hours and 4 hours, respectively. After a continuous 2 hours SGJ incubation and 4 hours SIJ incubation, the survivability of encapsulated L-NCFM with mannitol was $0 \%$. The cell count for encapsulated L-NCFM with mannitol after 4 hours of incubation in SIJ was $0 \log _{10}$ $\mathrm{CFU} / \mathrm{mL}$ indicating L-NCFM had been released from beads which could achieve the purpose of control release of these probiotics across the intestinal tract. Mannitol is able to retain encapsulated L-NCFM during exposure to simulated gastric juice, before releasing them steadily in simulated intestinal juice for over 3 hours. The alginate gel was not to protect the core cells making the core cells exposed to the external environment during incubation in SIJ. This period allowed for a control of release over the small intestine.

Storage test was conducted under refrigerator $\left(4{ }^{\circ} \mathrm{C}\right)$ and room temperature $\left(25^{\circ} \mathrm{C}\right)$ for a period of 4 weeks. The survivability of all three forms of bacteria were evaluated throughout this 4 weeks of storage. Figure 2 shows survival of free cells, encapsulated Lactobacillus acidophilus NCFM with and without mannitol in mulberry tea over 4 weeks of storage at refrigerator $\left(4^{\circ} \mathrm{C}\right)$ and room temperature $\left(25^{\circ} \mathrm{C}\right)$. From the figure, all three forms of L-NCFM which were free cell, encapsulated L-NCFM with and without mannitol showed a trend of decreasing over 4 weeks storage in mulberry tea under room temperature $\left(25^{\circ} \mathrm{C}\right)$.

Under storage at $25{ }^{\circ} \mathrm{C}$ after 1 week of storage, free cell had a drastic reduction of $60.23 \%$ from 8.75 $\log _{10} \mathrm{CFU} / \mathrm{mL}$ to $3.48 \log _{10} \mathrm{CFU} / \mathrm{mL}$. This result demonstrates that after 1 week of storage, free cell under 
$25{ }^{\circ} \mathrm{C}$ storage only had $10^{3} \mathrm{CFU} / \mathrm{mL}$ of cells which did not meet the minimum requirement of probiotic which needs to at least with $10^{6} \mathrm{CFU} / \mathrm{mL}$ of cells (Kechagia et al., 2013). After 1 week storage under $25^{\circ} \mathrm{C}$, free cell had experienced higher reduction in viable cells by $60.23 \%$ compared to encapsulated L-NCFM with and without prebiotic mannitol by $13.11 \%$ and $9.46 \%$, respectively. Encapsulated L-NCFM with and without mannitol had a higher survivability in mulberry tea throughout the 4 weeks of storage under $25{ }^{\circ} \mathrm{C}$. The current findings add substantially to our understanding of co-extrusion microencapsulation technique can protect the encapsulated L-NCFM and increase cell survivability under storage. Alginate-locust bean gum beads contributed to a lower exposure of the encapsulated cells to external environment, which resulted in high survivability of the alginate-locust bean gum beads compared to free cell form (Cheow, Kiew; Hadinoto, 2014).

The encapsulated L-NCFM with mannitol had higher survivability of $54.06 \%$ in mulberry tea throughout the storage of 4 weeks under $25^{\circ} \mathrm{C}$ compared to the free cell of $0 \%$ and encapsulated L-NCFM without mannitol of $17.38 \%$. This finding highlights the adding of prebiotic that had enhanced the cell survivability. Prebiotic increased Lactobacillus and Bifidobacterium cell growth and survivability as it can serve as probiotic's food (Bomhof et al., 2013). Pre-cultivation of bacteria with mannitol enhanced the survival of bacteria such as Lactobacillus (Succi et al., 2017).

Under $4{ }^{\circ} \mathrm{C}$, the storage of three forms of L-NCFM, which were free cell, encapsulated L-NCFM with and without mannitol in mulberry tea after 4 weeks showed a decreasing trend of their viable cell count. Free cell in mulberry tea at $4{ }^{\circ} \mathrm{C}$ had the lowest survivability of $0 \%$ during the storage test compared to the survivability of encapsulated L-NCFM with and without mannitol which were $78.89 \%$ and $67.26 \%$, respectively. This finding suggests that microencapsulation can help to protect the core cells and maintain the cell survivability under long term storage. Co-extrusion method of microencapsulation is a process in which the probiotic cells are entrapped within the coatings of hydrocolloidal materials in order to protect it from harsh environment condition, which maintain the cell growth and survivability (Mortazavian et al., 2008).

Encapsulated L-NCFM with prebiotic mannitol showed the highest survivability of $78.89 \%$ throughout the 4 weeks storage under $4^{\circ} \mathrm{C}$ compared to the rest of samples either under $4{ }^{\circ} \mathrm{C}$ or $25^{\circ} \mathrm{C}$. The final viable cell count of encapsulated L-NCFM with mannitol at week 4 under $4{ }^{\circ} \mathrm{C}$ was $6.80 \log 10 \mathrm{CFU} / \mathrm{mL}$ which it met the minimum level $\left(10^{6} \mathrm{CFU} / \mathrm{mL}\right)$ of probiotic required to exert benefit on human health, whereas other samples in this storage test were below the minimum requirement after

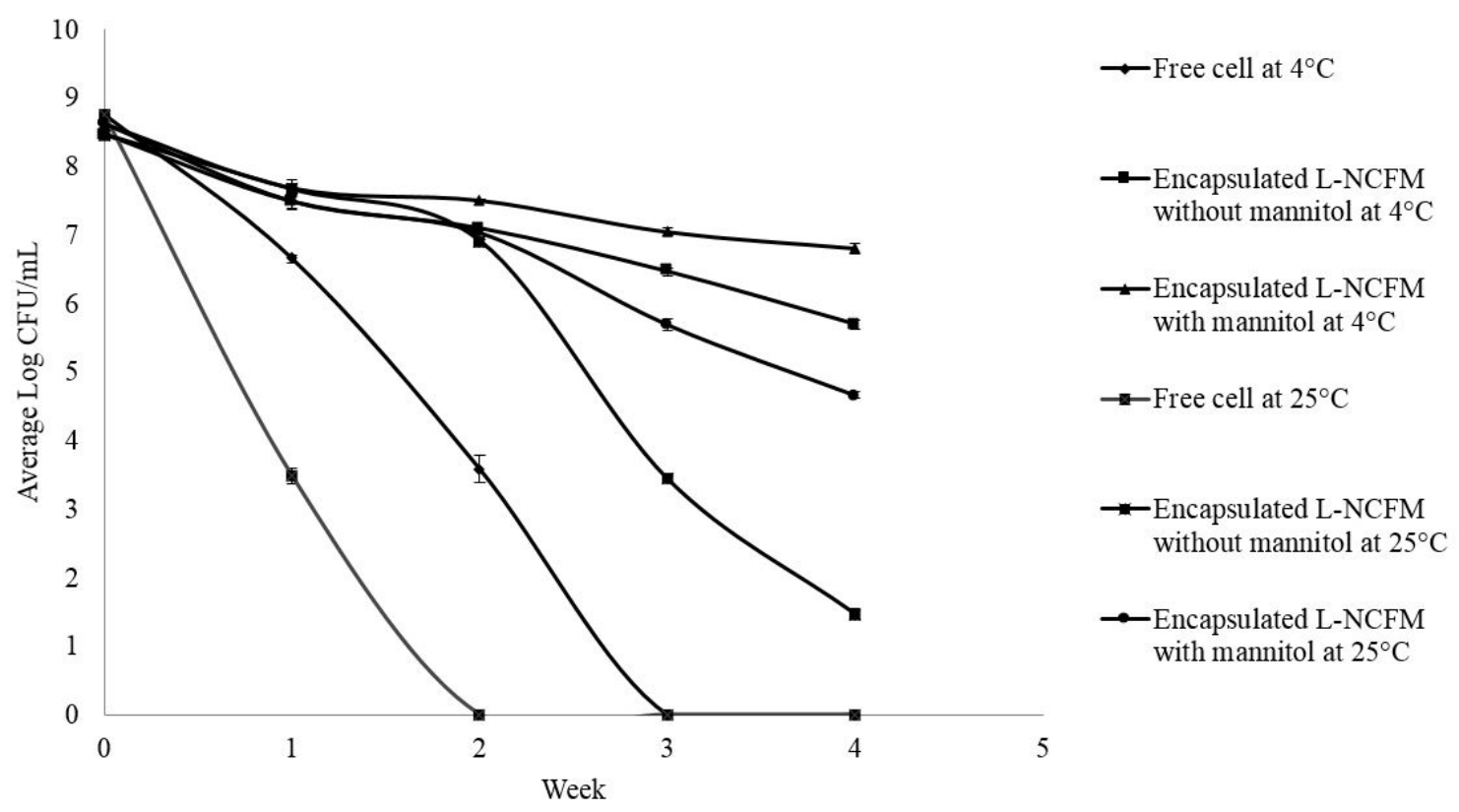

Figure 2: Survival of free cell, encapsulated Lactobacillus acidophilus NCFM with and without mannitol in mulberry tea over 4 weeks of storage at refrigerator $\left(4^{\circ} \mathrm{C}\right)$ and room temperature $\left(25^{\circ} \mathrm{C}\right)$. 
4 weeks of storage. This demonstrates the positive effect of incorporation of prebiotic into alginate matrix during microencapsulation on the survival of probiotic especially under $4{ }^{\circ} \mathrm{C}$ storage, in which this result is in agreement with Sathyabama et al. (2014).

These findings suggest that encapsulated L-NCFM was stable for 2 weeks at $25^{\circ} \mathrm{C}$. When mannitol was added, encapsulated L-NCFM was stable for 3 weeks, with the cell count more than the minimum required concentration of probiotics of $6 \log 10 \mathrm{CFU} / \mathrm{mL}$. At $4{ }^{\circ} \mathrm{C}$, encapsulated L-NCFM was stable for 3 weeks. Encapsulated L-NCFM with mannitol was stable for 4 weeks, with the cell count more than the minimum required concentration of probiotics of $6 \log 10 \mathrm{CFU} / \mathrm{mL}$.

\section{CONCLUSIONS}

In this study, Lactobacillus acidophilus NCFM (L-NCFM) was microencapsulated to improve its survivability in gastrointestinal condition and long term storage. Concentration of $3.0 \%(\mathrm{w} / \mathrm{v})$ mannitol and $0.5 \%(\mathrm{w} / \mathrm{v})$ locust bean gum were selected for further analysis as it could enhance the growth of L-NCFM with mannitol and produce bead with small size with high microencapsulation efficiency. Encapsulated L-NCFM beads produced are in spherical shape, white in colour with a thin surface layer with beads from $550 \mu \mathrm{m}$ to $700 \mu \mathrm{m}$ using optical microscope. The average microencapsulation efficiency is in between of $85.86 \%$ to $96.81 \%$. After 2 hours of SGJ incubation, the survivability of encapsulated L-NCFM with mannitol was higher than the survivability of encapsulated L-NCFM without mannitol by $1.86 \%$. Mannitol was found to enhance the survivability of encapsulated L-NCFM in SGJ incubation. However, the final survivability of L-NCFM after sequential incubation in SGJ and simulated intestinal juice (SIJ) was $0 \%$ which demonstrates that L-NCFM had been released from the beads. Mannitol is able to retain encapsulated L-NCFM during exposure to simulated gastric juice, before releasing them steadily in SIJ for over 3 hours. This period allowed for a control of release over the small intestine. After 4 weeks storage of encapsulated L-NCFM in mulberry tea under refrigerator temperature $\left(4^{\circ} \mathrm{C}\right)$ and room temperature $\left(25^{\circ} \mathrm{C}\right)$, mulberry tea incorporated with encapsulated L-NCFM with and without mannitol were cloudier than mulberry tea incorporated with free cell. Encapsulated L-NCFM with mannitol under $4{ }^{\circ} \mathrm{C}$ after 4 weeks had the highest L-NCFM survivability of $78.89 \%$ compared to other samples. Its viable cell count $(6.80$ $\log 10 \mathrm{CFU} / \mathrm{mL}$ ) was above the minimum required amount to be used as probiotic $(6 \log 10 \mathrm{CFU} / \mathrm{mL})$. At $25^{\circ} \mathrm{C}$, encapsulated L-NCFM was stable for 2 weeks, in which the cell count was above $6 \log 10 \mathrm{CFU} / \mathrm{mL}$. When mannitol was added, encapsulated L-NCFM was stable for 3 weeks, with the cell count more than the minimum required concentration of probiotics of $6 \log 10 \mathrm{CFU} / \mathrm{mL}$. At $4{ }^{\circ} \mathrm{C}$, encapsulated L-NCFM was stable for 3 weeks. When mannitol was added, encapsulated L-NCFM was stable for 4 weeks, with the cell count more than the minimum required concentration of probiotics of $6 \log 10 \mathrm{CFU} / \mathrm{mL}$. Thus, co-extrusion with mannitol as prebiotic can enhance the growth and survivability of L-NCFM in mulberry tea under $4{ }^{\circ} \mathrm{C}$.

\section{ACKNOWLEDGEMENT}

The project was supported by UCSI University Pioneer Scientist Incentive Fund (PSIF) grant (Proj-InFAS-055).

\section{REFERENCES}

ABBASZADEH, S. et al. The effect of alginate and chitosan concentrations on some properties of chitosan coated alginate bead and survivability of encapsulated Lactobacillus rhamnosus in simulated gastrointestinal conditions and during heat processing. Journal of the Science of Food and Agriculture, 94(11):2210-6, 2004.

ANGELOV, A. et al. Development of a new oat-based probiotic drink. International Journal of Food Microbiology, 112:75-80, 2006.

ANNAN, N.; BORZA, A.; HANSEN, L. Encapsulation in alginatecoated gelatin microspheres improves survival of the probiotic Bifidobacterium adolescentis 15703t during exposure to simulated gastro-intestinal conditions. Food Research International, 41(2):184-193, 2008.

ASEANLIP. Food Amendment No. 2 Regulations. 1983. Available in: <https://www.aseanlip.com/ malaysia/general/legislation/food-amendment-no-2regulations-2017/AL14658>. Access in: December, 17 2018.

BOMHOF, M. et al. Combined effects of oligofructose and Bifidobacterium animalison gut microbiota and glycemia in obese rats. Obesity, 22(3):763-771, 2013.

BRINQUES, G.; AYUB, M. Effect of microencapsulation on survival of Lactobacillus plantarum in simulated gastrointestinal conditions, refrigeration, and yogurt. Journal of Food Engineering, 103(2):123-128, 2011. 
BUTSTRAEN, C.; SALAÜN, F. Preparation of microcapsules by complex coacervation of gum arabic and chitosan. Carbohydrate Polymers, 99:608-616, 2014.

CHAN, E.; LYE, P.; WONG, S. Phytochemistry, pharmacology, and clinical trials of Morus alba. Chinese Journal of Natural Medicines, 14(1):17-30, 2016.

$\mathrm{CHEN}, \mathrm{H}$. et al. Effects of sugar alcohol and proteins on the survival of Lactobacillus bulgaricus LB6 during freeze drying. Acta Scientiarum Polonorum, Technologia Alimentaria, 14:(2)117-124, 2015.

CHEOW, W.; KIEW, T.; HADINOTO, K. Controlled release of Lactobacillus rhamnosus biofilm probiotics from alginatelocust bean gum microcapsules. Carbohydrate Polymers, 103:587-595, 2014.

CHEW, S. et al. In-vitro evaluation of kenaf seed oil in chitosan coated-high methoxyl pectin-alginate microcapsules. Industrial Crops and Products, 76:230-236, 2015.

CHIA, P. et al. Hydrogel beads from sugar cane bagasse and palm kernel cake, and the viability of encapsulated Lactobacillus acidophilus. Polymers, 15(6):1-9, 2015.

COOK, M. et al. Microencapsulation of probiotics for gastrointestinal delivery. Journal of Controlled Release, 162:56-67, 2012.

DEEPA, M. et al. Purified mulberry leaf lectin (MLL) induces apoptosis and cell cycle arrest in human breast cancer and colon cancer cells. Chemico-Biological Interactions, 200(1):38-44, 2012.

DU, Q.; ZHENG, J.; XU, Y. Composition of anthocyanins in mulberry and their antioxidant activity. Journal of Food Composition and Analysis, 21(5):390-395, 2008.

FIQUEROA-GONZALEZ, I. et al. Probiotics and prebiotics Perspectives and challenges. Journal of the Science of Food and Agriculture, 91(8):1341-1348, 2011.

FOOD AND AGRICULTURE ORGANIZATION AND WORLD HEALTH ORGANIZATION. Guidelines for the evaluation of probiotics in food. 1-11, 2002.

GANDOMI, $\mathrm{H}$. et al. Effect of chitosan-alginate encapsulation with inulin on survival of Lactobacillus rhamnosus GG during apple juice storage and under simulated gastrointestinal conditions. LWT - Food Science and Technology, 69:365$371,2016$.

GAWKOWSKI, D.; CHIKINDAS, M. Non-dairy probiotic beverages: The next step into human health. Beneficial Microbes, 4(2):127-142, 2013.
GRANATO, D. et al. Functional foods and nondairy probiotic food development: Trends, concepts, and products. Comprehensive Reviews in Food Science and Food Safety, 9(3):292-302, 2010.

HAGHSHENAS, B. et al. Effect of addition of inulin and fenugreek on the survival of microencapsulated Enterococcus durans 39C in alginate-psyllium polymeric blends in simulated digestive system and yogurt. Asian Journal of Pharmaceutical Sciences, 10(4):350-361, 2015.

HANSEN, L. et al. Survival of Ca-alginate microencapsulated Bifidobacterium spp. in milk and simulated gastrointestinal conditions. Food Microbiology, 19(1):35-45, 2002.

HARAUMA, A. etal. Mulberry leaf powder prevents atherosclerosis in apolipoprotein E-deficient mice. Biochemical and Biophysical Research Communications, 358(3):751-756, 2007.

JYOTHI, N. et al. Microencapsulation techniques, factors influencing encapsulation efficiency. Journal of Microencapsulation, 27(3):187-197, 2010.

KECHAGIA, M. et al. Health benefits of probiotics: A review. International Scholarly Research Network Nutrition, 2013:1-7, 2013.

$\mathrm{KIM}$, S. et al. Effect of microencapsulation on viability and other characteristics in Lactobacillus acidophilus ATCC 43121. LWT - Food Science and Technology, 41(3):493-500, 2008.

KRASAEKOOPT, W. Microencapsulation of probiotics in hydrocolloid gel matrices: A review. Agro Food Industry Hi Tech, 24(2):761-766, 2013.

KUMAR, V. R.; CHAUHAN, S. Mulberry: Life enhancer. Journal of Medicinal Plant Research, 2(10):271-278, 2008.

LOTFIPOUR, F.; MIRZAEEI, S.; MAGHSOODI, M. Evaluation of the effect of $\mathrm{CaCl}_{2}$ and alginate concentrations and hardening time on the characteristics of Lactobacillus acidophilus loaded alginate beads using response surface analysis. Advanced Pharmaceutical Bulletin, 2(1):71-78, 2012.

MORTAZAVIAN, A. M. et al. Viability of calcium-alginatemicroencapsulated probiotic bacteria in Iranian yogurt drink (Doogh) during refrigerated storage and under simulated gastrointestinal conditions. Australian Journal of Dairy Technology, 63:25-30, 2008.

NAZZARO, F. et al. Fermentative ability of alginate-prebiotic encapsulated Lactobacillus acidophilus and survival under simulated gastrointestinal conditions. Journal of Functional Foods, 1(3):319-323, 2009. 
OOI, L.; LIONG, M. Cholesterol-lowering effects of probiotics and prebiotics: A review of in vivo and in vitro findings. International Journal of Molecular Sciences, 11(6):24992522, 2010.

ORTAKEI, F.; SERT, S. Stability of free and encapsulated Lactobacillus acidophilus ATCC 4356 in 389 yogurt and in an artificial human gastric digestion system. Journal of Dairy Science, 95(12):6918-25, 2012.

PENG, C. et al. Mulberry water extracts possess an anti-obesity effect and ability to inhibit hepatic lipogenesis and promote lipolysis. Journal of Agricultural and Food Chemistry, 59(6):2663-2671, 2011.

SANDER, M. E. How do we know when something called "probiotic" is really a probiotic? A guideline for consumers and health care professionals. Functional Food Review, 1:3-12, 2009.

SATHYABAMA, S. et al. Co-encapsulation of probiotics with prebiotics on alginate matrix and its effect on viability in simulated gastric environment. LWT - Food Science and Technology, 57(1):419-425, 2014.

SHEWALE, R. N. et al. Selection criteria for probiotics: A review. International Journal of Probiotics and Prebiotics, 9(1):17-22, 2014.

SHI, L. et al. Encapsulation of Lactobacillus bulgaricus in carrageenan-locust bean gum coated milk microspheres with double layer structure. LWT - Food Science and Technology, 54(1):147-151, 2013.

SHURKHNA, R. A. et al. Modeling of lactic acid fermentation of leguminous plant juices. Applied Biochemistry and Microbiology, 42:204-209, 2006.
SOHAIL, A.; TURNER, M. S.; COOMBES, A. The viability of Lactobacillus rhamnosus GG 502 and Lactobacillus acidophilus NCFM following double encapsulation in alginate and 503 maltodextrin. Food and Bioprocess Technology, 6(10):2763-2769, 2013.

SOODBAKHSH, S. et al. Viability of encapsulated Lactobacillus casei and Bifidobacterium lactis in synbiotic frozen yogurt and their survival under in vitro simulated 419 gastrointestinal conditions. International Journal of Probiotics and Prebiotics, 7(3):121-128, 2012.

SUCCl, M. et al. Pre-cultivation with selected prebiotics enhances the survival and the stress response of Lactobacillus rhamnosus strains in simulated gastrointestinal transit. Frontiers in Microbiology, 8(1067):1-11, 2017.

TAUFIK, Y.; WIDIANTARA, T.; GARNIDA, Y. The effect of drying temperature on the antioxidant activity of black mulberry leaf tea (Morus nigra). Rasayan Journal of Chemistry, 9(4):889-895, 2016.

YEO, S.; LIONG, M. Effect of prebiotics on viability and growth characteristics of probiotics in soymilk. Journal of the Science of Food and Agriculture, 90(2):267275, 2010.

ZANJANI, M. et al. Promoting Lactobacillus casei and Bifidobacterium adolescentis survival by microencapsulation with different starches and chitosan and poly L-lysine coatings in ice cream. Journal of Food Processing and Preservation, 42(1):1-10, 2017. 